\title{
Ameloblastic fibro-odontoma: A conservative surgical approach
}

\author{
Jairo-Evangelista Nascimento, Leonardo-de Jesus Araújo, Luciana-Yamamoto de Almeida, Alfredo-Maurí- \\ cio De Paula, Paulo-Rogério Bonan
}

Stomatology Clinic, Dental School, University of Montes Claros, UNIMONTES, Minas Gerais, Brazil

Correspondence:

Stomatology Clinic,

School of Dentistry,

State University of Montes Claros,

Montes Claros, Minas Gerais, Brazil.

pbonan@yahoo.com

Received: $18 / 02 / 2009$

Accepted: 08/06/2009

Nascimento JE, Araújo LJ, Almeida LY, De-Paula AM, Bonan PR. Ameloblastic fibro-odontoma: A conservative surgical approach. Med Oral Patol Oral Cir Bucal. 2009 Dec 1;14 (12):e654-7. http://www.medicinaoral.com/medoralfree01/v14i12/medoralv14i12p654.pdf

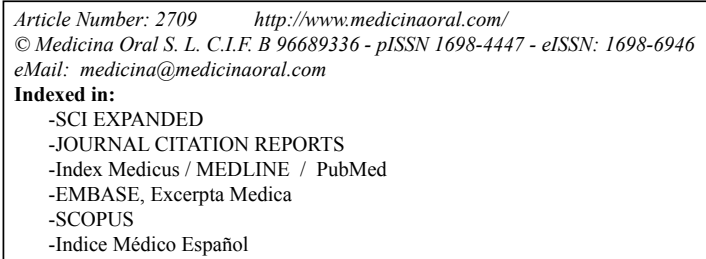

\begin{abstract}
Ameloblastic fibro-odontoma (AFO) is a rare benign mixed odontogenic tumor that occurs predominantly in children and young adults with no gender predilection and anatomic site, usually appearing as a painless swelling. We present a case of an 11-year-old non-Caucasian boy complaining of large painless isolated swelling in the right mandibular body. Intraoral examination revealed a tumoral mass with cortical bone expansion, covered by normal mucosa measuring $4.0 \times 2.0 \mathrm{~cm}$, located on both the lingual and buccal surfaces of the right body of the mandible, with displacement of the neighboring teeth. Panoramic radiography revealed an expansile, radiolucent and well circumscribed lesion with scattered foci of calcified material, which contained several radiopaque bodies of varying sizes and shapes. The provisional diagnoses were odontoma or AFO/ Biopsy confirmed AFO. The patient was treated with conservative surgery. After two years of follow-up, no alteration or recurrence was detected.
\end{abstract}

Key words: Odontogenic tumor, ameloblastic fibro-odontoma, surgery.

\section{Introduction}

Ameloblastic fibro-odontoma (AFO) is a rare mixed odontogenic tumour which consists of both odontogenic epithelium and ectomesenchyme proliferation with dental hard tissue formation (dentin and enamel matrix formation), representing about $3.1 \%$ of all odontogenic tumors (1-3). The mean age of the patients affected is between 8 to 12 years, and there is no gender or anatomic site predilection, although some studies relate slight involvement of posterior mandible $(2,4)$. Most of the cases are painless swelling and may be occasionally detected as a result of failure of tooth eruption $(2,3,5-7)$. Radiographically, AFO shows a well-defined unilocular or multilocular radiolucency containing various amounts of radiopaque material of irregular size and morphology (2,5-6). The recommended treatment of AFO is conservative enucleation with curettage (8). The prognosis is excellent $(1,5)$. The purpose of this article is to describe a case of a large AFO affecting the right mandibular body of a patient treated with conservative surgery without alteration or recurrence after two years of follow-up.

\section{Case Report}

An 11-year-old boy, non-caucasian, was referred to Stomatology Clinic, Dental School, University of Montes Claros, Montes Claros city, Brazil, due to a swelling affecting the right side of the mandible, during 5 years. The medical, social and family histories were unremark- 
able, as were the results of a review of systems and a physical examination. Extra-oral examination showed a painless swelling on the right mandibular body, of firm consistency on the palpation, which caused mode-rate facial asymmetry. Intraoral examination revealed a tumoral mass with great cortical bone expansion, covered by normal mucosa measuring $4.0 \times 2.0 \mathrm{~cm}$, located on both the lingual and vestibular faces of the right body of the mandible, with discrete displacement of neighboring teeth. Panoramic radiography exhibited an expansile, radiolucent, well circumscribed lesion with scattered foci of calcified material which contained several radiopaque bodies of varying sizes and shapes. The right lower canine, right lower first premolar and right lower second premolar had been displaced infe-riorly at level of cortical basal of the mandible, whereas that the right lower canine and right lower first molar (both deciduous) showed the roots reabsorbed, and the adjacent permanent incisors displayed their roots displaced in medial position. These findings are illustrated on Figure 1. The provisional diagnoses were odontoma or

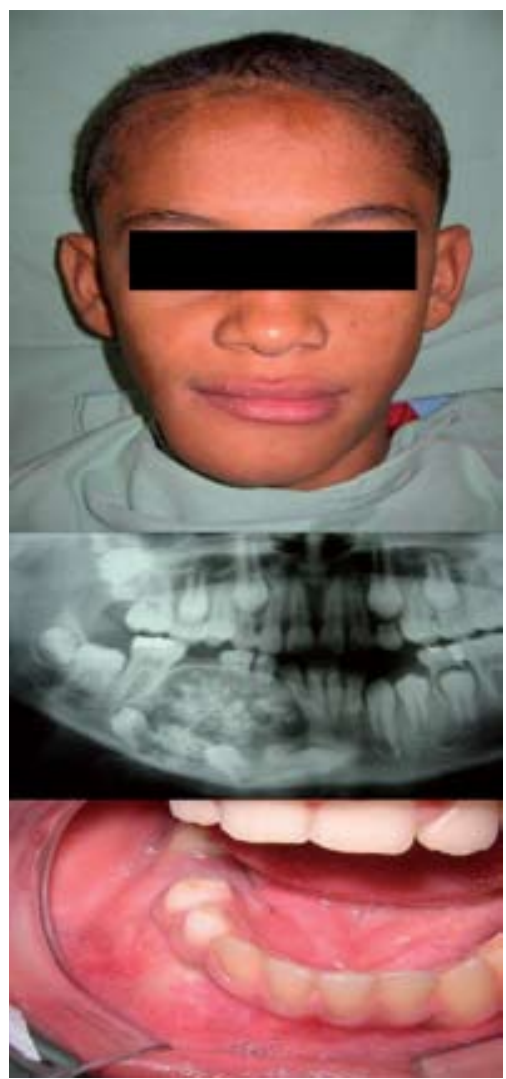

Fig. 1. (Above) Extra-oral examination showing a swelling on the right mandibular body, of hard consistency on the palpation, which caused moderate facial asymmetry. (Middle) Panoramic radiography exhibiting in the right place of mandible a well circumscribed lesion with scattered foci of calcified material which contained several radiopaque bodies of varying sizes and shapes. (Below) Intraoral examination revealing a tumoral mass with great cortical bone expansion, covered by normal mucosa with discrete displacement of neighboring teeth.
AFO. It was performed an incisional biopsy under local anesthesia. Microscopically, islands, strands, cords of odontogenic epithelium and areas of dentin and enamel matrix embedded in a cell-rich ectomesenchyme resembling dental papilla (Fig. 2).

The final diagnosis was AFO. The patient underwent enucleation of the lesion and careful curettage of the surgical cavity. Histopathological analysis of the resected specimen showed similar features of the incisional biopsy. After two years of follow-up no recurrence or alterations were detected (Fig. 3).

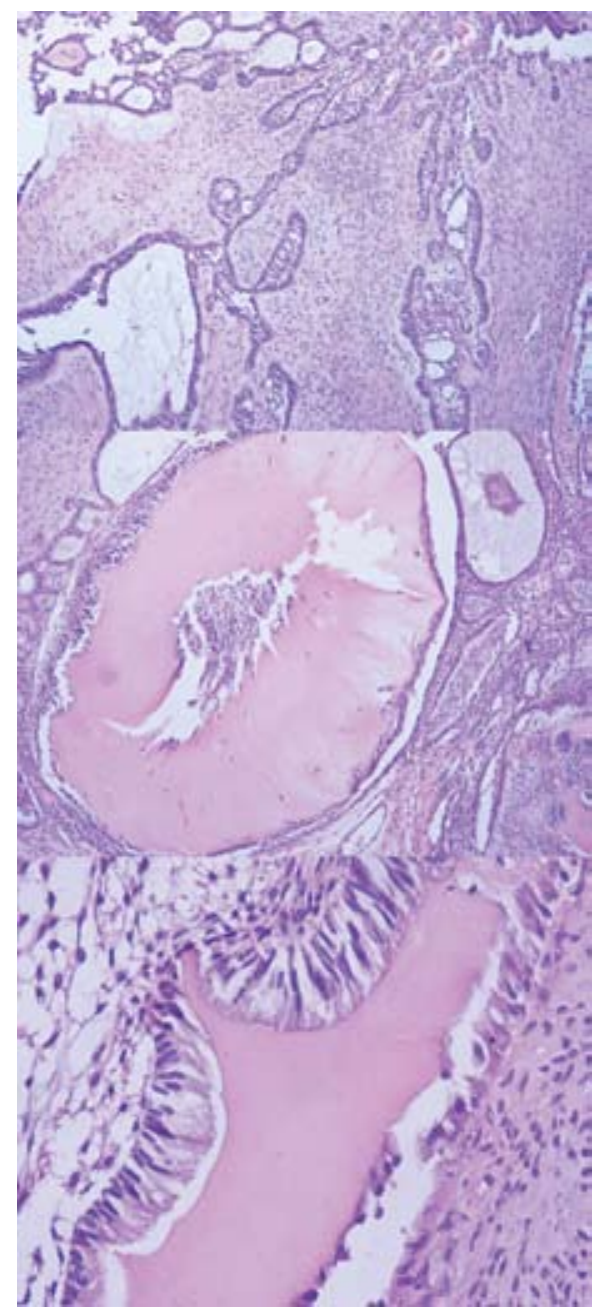

Fig. 2. (Above) Microscopically is possible to see islands, strands, cords of odontogenic epithelium merged in a tissue resembling dental papilla (HE,X100). (Middle) Low magnification showing the islands of odontogenic epithelium and a hyaline tissue resembling dentin. It was possible to observe a basophilic material (at right) resembling enamel component (HE, X100). (Below) High magnification showing the columnar ameloblastic cells, dentin and odontoblastic cells. A tissue seemed with dental papilla is also showed ((HE, X400). 


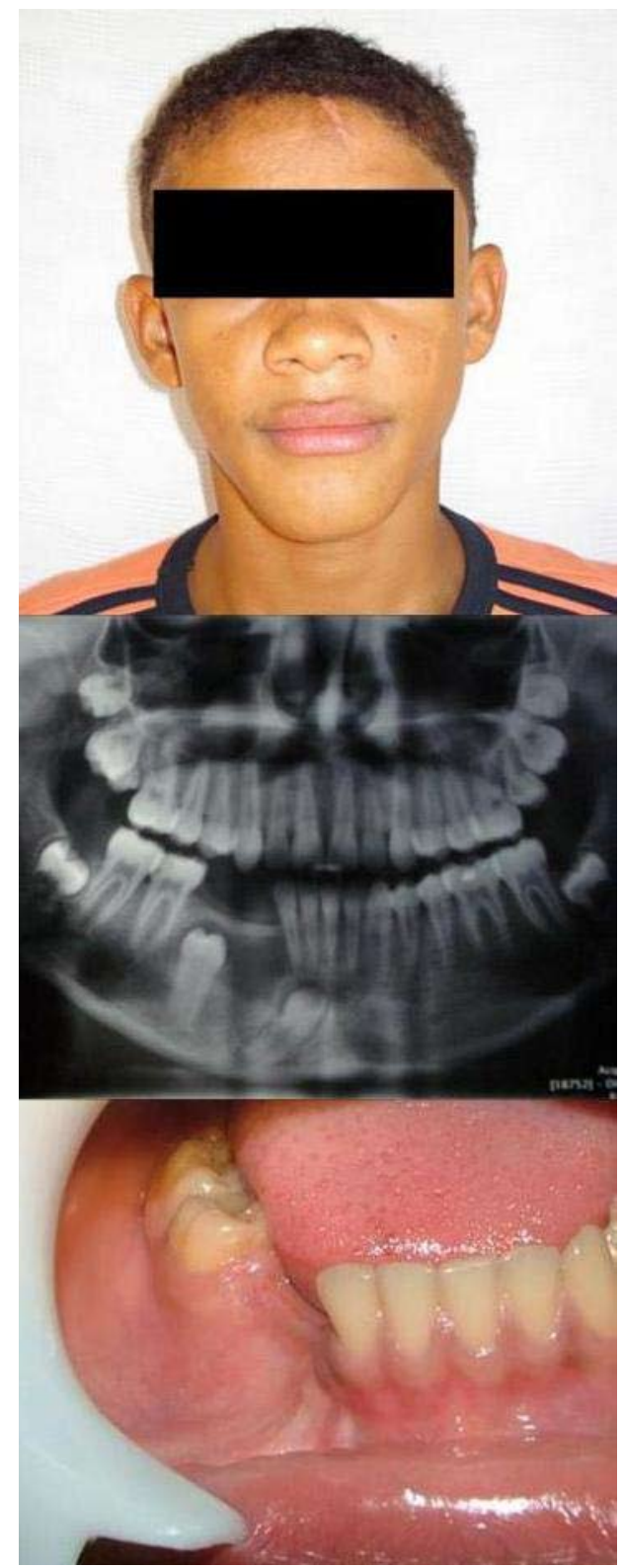

Fig. 3. (Above) Post surgical extra-oral examination showing reduced facial asymmetries. (Middle) Panoramic radiography exhibited ossification at original place of the lesion. Note the right lower second premolar in route of eruption and the impacted right lower first premolar, probably needing a future surgical approach. (Below) Intraoral examination revealing a complete healing without bone expansion.

\section{Discussion}

AFO is a neoplasm composed of proliferating odontogenic epithelium embedded in a cellular ectomesenchymal tissue that resembles dental papilla, and with varying degrees of inductive change that lead to the formation of both dentin and enamel $(1-3,5,8)$. This lesion is usually found in the molar area, with discrete predilection in mandible and, occurs mainly in young people (less than 20 years old) (5). The Table 1 described the some published cases in the English literature cited is this article. Radiografi- cally, the tumour appears as a uni or multilocular radiolucency with a well-defined boundary often exhibiting a radiopaque border (6). The ratio of radiopaque to radiolucent areas differs from one lesion to another; sometimes the mineralized element in the tumour predominates and the lesion may resemble a complex odontoma (5). Surgical procedure showed a well-circumscribed tumoral mass containig within several amounts of small irregular hard masses. Thus, our findings also place in evidences the benign nature of this tumor, and emphasize the conservative surgical but careful management (8).

The distinction between developing complex odontoma and an AFO is impossible sometimes. However the presence of great amounts of enamel, dentin, and cementum-like tissue arranged in a haphazard pattern favors odontoma diagnosis. Moreover, it is necessary the distinction between AFO and odontoameloblastoma. In this lesion, the epithelial component is typical of ameloblastoma and the fibrous stroma shows cellular myxoid tissue adjacent to the mineralized dental tissues (9). Ameloblastic fibrodentinoma (AFD) is considered by some authors as a stage between the ameloblastic fibroma (AF) and AFO based on the extent of histodifferentiation (7). Microscopically, AFO is histomorphologically similar to the AFD. The difference is that the AFO is characterized by showing not only osteodentin or dentin-like material, but also by the production of enamel matrix (6). In relation to the AF, no dental hard tissues are present in this lesion (8) and it has a potential to both recurrence and malignant transformation $(4,10)$. The age of patients and the size of the lesion at initial discovery could be the important factors in judging the behavior and the nature of the lesions (7). The microscopic evaluation of the specimen of our case showed typical features of both epithelial and ectomesenchymal components, supporting the diagnosis of AFO.

The treatment of AFO is associated with conservative surgical approach (11-14). Sporadic recurrences of AFO have been attributed to the inadequate surgical removal at the time of initial treatment $(7,8,12)$. A previous case of AFO was treated with enucleation and preservation of an impacted lower left first permanent molar showed no signs of recurrence and complete spontaneous eruption of the preserved tooth (2). Other report demonstrated that a conservative enucleation with curettage followed by abundant irrigation was successful to prevent recurrences (12). There is no consensus about the dental maintaining after AFO surgery due increased rate of recurrence $(5,13)$. Nevertheless, some clinical reports revealed success without dental management with posterior dental eruption without tumoral return $(2,13)$. In summary, we report a case of a large AFO affecting an 11-year-old boy involving the right posterior side of mandible. In this case, the conservative surgical approach was the treatment of choice. 
Table 1. Analysis of some clinical studies focusing the AFO.

\begin{tabular}{|c|c|c|c|c|c|c|c|}
\hline $\begin{array}{c}\text { Authors/Year/ } \\
\text { Reference }\end{array}$ & Cases & Gender & Age & Location & Imaginologic Findings & Treatment & Follow-up \\
\hline $\begin{array}{c}\text { Chang et } \\
\mathrm{al} / 2002(5)\end{array}$ & 01 & $\begin{array}{l}\text { Female } \\
(01)\end{array}$ & $\begin{array}{c}26 \\
\text { years }\end{array}$ & $\begin{array}{l}\text { Mandible } \\
\text { (01) }\end{array}$ & $\begin{array}{l}\text { Expansille, well-circumscribed, } \\
\text { radiolucent lesion around a impacted } \\
\text { lower left third molar. }\end{array}$ & Enucleation & 12 months \\
\hline $\begin{array}{l}\text { Dolanmaz et al } \\
\qquad / 2008(1)\end{array}$ & 01 & $\begin{array}{l}\text { Female } \\
(01)\end{array}$ & $\begin{array}{c}09 \\
\text { years }\end{array}$ & $\begin{array}{l}\text { Maxilla } \\
\text { (01) }\end{array}$ & $\begin{array}{l}\text { Large lobular radiopaque mass with } \\
\text { a radiolucent border covering the } \\
\text { complete right maxillary sinus. }\end{array}$ & Enucleation & 03 years \\
\hline $\begin{array}{l}\text { Friedrich et } \\
\text { al./2001(14) }\end{array}$ & 01 & $\begin{array}{l}\text { Male } \\
(01)\end{array}$ & $\begin{array}{c}08 \\
\text { years }\end{array}$ & $\begin{array}{l}\text { Mandible } \\
\quad(01)\end{array}$ & $\begin{array}{l}\text { Well-defined radiolucent region } \\
\text { surrounding a centrallylocated ra- } \\
\text { diopaque region. }\end{array}$ & $\begin{array}{l}\text { Enucleation } \\
\text { and Curet- } \\
\text { tage }\end{array}$ & 24 months \\
\hline $\begin{array}{l}\text { Oghli. et al } \\
\text { /2007 (3) }\end{array}$ & 01 & $\begin{array}{l}\text { Male } \\
(01)\end{array}$ & $\begin{array}{c}03 \\
\text { years }\end{array}$ & $\begin{array}{l}\text { Mandible } \\
\quad(01)\end{array}$ & $\begin{array}{l}\text { Well-defined radiolucent region } \\
\text { surrounding with several radiopaque } \\
\text { bodies of varying sizes and shapes. }\end{array}$ & Enucleation & 4 years \\
\hline $\begin{array}{c}\text { Reis et al / } 2007 \\
\text { (2) }\end{array}$ & 01 & $\begin{array}{l}\text { Female } \\
(01)\end{array}$ & $\begin{array}{c}06 \\
\text { years }\end{array}$ & $\begin{array}{l}\text { Mandible } \\
\quad(01)\end{array}$ & $\begin{array}{l}\text { Large radiopaque image enveloped } \\
\text { by a radiolucent zone extending from } \\
\text { the region of the left permanent first } \\
\text { molar to the posterior limit of man- } \\
\text { dibular body. }\end{array}$ & $\begin{array}{l}\text { Enucleation } \\
\text { and Curet- } \\
\text { tage }\end{array}$ & 24 months \\
\hline $\begin{array}{c}\text { Zouhary et } \\
\text { al./2008 (12) }\end{array}$ & 01 & $\begin{array}{l}\text { Female } \\
(01)\end{array}$ & $\begin{array}{c}07 \\
\text { years }\end{array}$ & $\begin{array}{c}\text { Maxilla } \\
(01)\end{array}$ & $\begin{array}{l}\text { Multiple dense radiopaque densities } \\
\text { consistent with malformed tooth } \\
\text { material within the lesion. }\end{array}$ & Enucleation & 06 moths \\
\hline
\end{tabular}

\section{References}

1. Dolanmaz D, Pampu AA, Kalayci A, Etöz OA, Atici S. An unusual size of ameloblastic fibro-odontoma. Dentomaxillofac Radiol. 2008;37:179-82.

2. Reis SR, De Freitas CE, Do Espírito Santo AR. Management of ameloblastic fibro-odontoma in a 6 -year-old girl preserving the associated impacted permanent tooth. J Oral Sci. 2007;49:331-5.

3. Oghli AA, Scuto I, Ziegler C, Flechtenmacher C, Hofele C. A large ameloblastic fibro-odontoma of the right mandible. Med Oral Patol Oral Cir Bucal. 2007;12:E34-7.

4. Gyulai-Gaál S, Takács D, Szabó G, Suba Z. Mixed odontogenic tumors in children and adolescents. J Craniofac Surg. 2007;18:133842.

5. Chang H, Precious DS, Shimizu MS. Ameloblastic fibro-odontoma: a case report. J Can Dent Assoc. 2002;68:243-6.

6. Philipsen HP, Reichart PA, Praetorius F. Mixed odontogenic tumours and odontomas. Considerations on interrelationship. Review of the literature and presentation of 134 new cases of odontomas. Oral Oncol. 1997;33:86-99.

7. Chen Y, Li TJ, Gao Y, Yu SF. Ameloblastic fibroma and related lesions: a clinicopathologic study with reference to their nature and interrelationship. J Oral Pathol Med. 2005;34:588-95.

8. Martín-Granizo López R, Ortega L, González Corchón MA, Berguer Sández A. Ameloblastic fibroma of the mandible. Report of two cases. Med Oral. 2003;8:150-3.
9. Martín-Granizo-López R, López-García-Asenjo J, De-PedroMarina M, Domínguez-Cuadrado L. Odontoameloblastoma: a case report and a review of the literature. Med Oral. 2004;9:340-4.

10. Chen Y, Wang JM, Li TJ. Ameloblastic fibroma: a review of published studies with special reference to its nature and biological behavior. Oral Oncol. 2007;43:960-9.

11. Atwan S, Geist JR. Ameloblastic fibro-odontoma: case report and review of the literature. J Mich Dent Assoc. 2008;90:46-9.

12. Zouhary KJ, Said-A1-Naief N, Waite PD. Ameloblastic fibro-odontoma: expansile mixed radiolucent lesion in the posterior maxilla: a case report. Oral Surg Oral Med Oral Pathol Oral Radiol Endod. 2008;106:e15-21.

13. Okura M, Nakahara H, Matsuya T. Treatment of ameloblastic fibro-odontoma without removal of the associated impacted permanent tooth: report of cases. J Oral Maxillofac Surg. 1992;50:1094-7. 14. Friedrich RE, Siegert J, Donath K, Jäkel KT. Recurrent ameloblastic fibro-odontoma in a 10-year-old boy. J Oral Maxillofac Surg. 2001;59:1362-6.

\section{Acknowledgment:}

To FAPEMIG (Foundation of Research Support of Minas Gerais State) due to our financial support. 